\title{
Retraction: Atorvastatin May Attenuate Recurrence of Chronic \\ OPEN ACCESS Subdural Hematoma
}

Approved by:

Arjan Blokland,

Maastricht University, Netherlands

*Correspondence: Frontiers Editorial Office editorial.office@frontiersin.org

Specialty section:

This article was submitted to

Neuropharmacology,

a section of the journal

Frontiers in Neuroscience

Received: 27 September 2016

Accepted: 27 September 2016

Published: 07 October 2016

Citation:

Frontiers Editorial Office (2016)

Retraction: Atorvastatin May Attenuate

Recurrence of Chronic Subdural Hematoma. Front. Neurosci. 10:465.

doi: 10.3389/fnins.2016.00465

\section{Frontiers Editorial Office *}

\section{A retraction of the Original Research Article}

Atorvastatin May Attenuate Recurrence of Chronic Subdural Hematoma by Liu, H., Luo, Z., Liu, Z., Yang, J., and Kan, S. (2016). Front. Neurosci. 10:303. doi: 10.3389/fnins.2016.00303

The Journal and Authors retract the 28 June 2016 article cited above for the following reasons provided by the Authors:

In one of our collaborating centers (The People's Hospital of AnQiu City), 38 patients were enrolled in an atorvastatin group. Among them, 26 patients lost to follow-up were categorized and analyzed as "non-recurrence group." It was a fundamental error and thus we must retract this article. We apologize for any inconvenience caused by the retraction of this article.

Copyright $(2016$ Frontiers Editorial Office. This is an open-access article distributed under the terms of the Creative Commons Attribution License (CC BY). The use, distribution or reproduction in other forums is permitted, provided the original author(s) or licensor are credited and that the original publication in this journal is cited, in accordance with accepted academic practice. No use, distribution or reproduction is permitted which does not comply with these terms. 